\title{
Therapeutic potential of harmaline, a novel alkaloid, against cervical cancer cells in vitro: Apoptotic induction and DNA interaction study
}

\author{
Paromita Bhattacharjee, Sarita Sarkar, Tapas Ghosh, Kakali Bhadra* \\ Department of Zoology, University of Kalyani, Kalyani, Nadia, India.
}

\begin{tabular}{l}
\hline ARTICLE INFO \\
\hline Article history: \\
Received on: February 17, 2018 \\
Accepted on: March 14, 2018 \\
Available online: May 22, 2018 \\
\hline Key words: Beta carboline, \\
Cytotoxicity, Reactive oxygen species, \\
Spectroscopy, Isothermal calorimeter.
\end{tabular}

\section{INTRODUCTION}

Cervical cancer is the third most frequently occurring cancer, and the fourth leading cause of cancer mortality in women worldwide, with an estimation of 530,000 new cases and 175,000 mortality each year [1]. Nucleic acid, chiefly DNA which is the main hereditary and genetic element of the cell, is the target biomolecule in the evolution of cancer. The use of alkaloids as medicine by humans date back thousands of years and the most important of them includes morphine, quinine, taxol, camptothecin, and berberine. Besides other pharmacological importance, plant alkaloids have been found to be potent anti-cancer agent targeting deoxyribonucleic acids [2-6]. Beta carboline alkaloids are one of such plant alkaloids, which have proven to be highly cytotoxic with several biological and nucleic acid binding effects [7-9]. Recently, they have also been proved to cause oxidative modification of low-density lipoprotein particles, which can reduce severe atherosclerosis [10]. Harmaline [Figure 1], a di-hydro beta carboline alkaloid, is such a plant alkaloid isolated from the seeds and roots of Peganum harmala (Syrian rue) [11] and have wide range of biological actions including anti-leishmanial [12], insecticidal [13], acetylcholinesterase inhibition [14], central monoamine oxidase

*Corresponding Author:

Kakali Bhadra, Department of Zoology, University of Kalyani, Kalyani, Nadia, 741235, India.

E-mail: kakali_bhadra2004@yahoo.com inhibition [15], and in vitro human topoisomerase I inhibition effects [16] and in vitro cytotoxic effects [17]. Another beta carboline alkaloid harmine and its derivatives were also proved to be cytotoxic against different cancer cell lines [18].

Previously, harmalol, another naturally occurring beta carboline alkaloid, have been reported to have strong in-vitro cytotoxic ability [19-21] and also have binding potential with nucleic acids $[22,23]$. Hence, with reference to our previous investigation, in this study we have tried to explore the binding and cytotoxic ability of harmaline on human cervical carcinoma (HeLa) cell line in detail using different biophysical, calorimetric, and biochemical assays. This research will help to design DNA based cancer therapeutic drug in the future.

\section{MATERIALS AND METHODS}

\subsection{Materials}

Harmaline hydrochloride was obtained from Sigma-Aldrich (St. Louis, MO, USA). Its concentration was determined using molar extinction coefficient value of $18,527 \mathrm{M}^{-1} / \mathrm{cm}$ at $371 \mathrm{~nm}$. CT DNA was also purchased from Sigma-Aldrich. Concentration was determined using the molar extinction coefficient $(\varepsilon)$ of $6600 \mathrm{M}^{-1} / \mathrm{cm}$ at $260 \mathrm{~nm}$ as described earlier $[22,24,25]$. Harmaline and CT DNA were dissolved in $15 \mathrm{mM}$ Citrate-Phosphate (CP) buffer of $\mathrm{pH} 6.8$. 


\subsection{Cell Viability Test and Other Biochemical Assays}

\subsubsection{MTT assay}

HeLa and WRL-68 cells were obtained from National Centre for Cell Science Pune. Cell growth protocols were followed as described earlier. Cells were grown in DMEM (HiMedia) medium supplemented with $10 \%$ heat inactivated fetal bovine serum (HiMedia) and $1 \%$ antibiotic antimycotic solution (HiMedia), at $37^{\circ} \mathrm{C}$ with $5 \% \mathrm{CO}_{2}$. The percentage of viable cells were calculated as the $\mathrm{GI}_{50} 50 \%$ growth inhibition) values for the cell lines by MTT ( $1 \mathrm{mg} / \mathrm{mL}$ of the MTT) assay kit (Sigma), by the following formula as reported earlier $[20,26]$.

$\mathrm{GI}_{50}=\left(\mathrm{T}-\mathrm{T}_{\mathrm{O}}\right) \times 100 /\left(\mathrm{C}-\mathrm{T}_{\mathrm{O}}\right)$

Where, $T$ represents the optical density of the sample culture plate after $48 \mathrm{~h}$ of harmaline treatment, $\mathrm{T}_{\mathrm{o}}$ is the optical density at time zero and $\mathrm{C}$ is the optical density of control. The average value of three independent experiments was taken.

\subsubsection{Lactate dehydrogenase ( $\mathrm{LDH}$ ) enzyme assay}

LDH activity was measured for both untreated and treated cells by following the work done by Biswas et al. [27] using Coral, India, LDH assay kit. HeLa cells $\left(2 \times 10^{4}\right.$ cells $/ 35 \mathrm{~mm}$ culture plate $)$ were treated with various concentration of harmaline $(13,28$ and $37 \mu \mathrm{M})$ at $37^{\circ} \mathrm{C}$ for $48 \mathrm{~h}$. Percent viable, apoptotic and necrotic cells were determined as our previous work [20].

$\%$ apoptosis $=\left(\mathrm{LDH}_{\mathrm{p}} \times 100 \%\right) /\left(\mathrm{LDH}_{\mathrm{p}}+\mathrm{LDH}_{\mathrm{i}}+\mathrm{LDH}_{\mathrm{e}}\right)$

$\%$ necrosis $=\left(\mathrm{LDH}_{\mathrm{e}} \times 100 \%\right) /\left(\mathrm{LDH}_{\mathrm{p}}+\mathrm{LDH}_{\mathrm{i}}+\mathrm{LDH}_{\mathrm{e}}\right)$

After collecting the suspended cells from culture media by centrifugation (3000 r.p.m for $4 \mathrm{~min}$ at $4^{\circ} \mathrm{C}$ ), the $\mathrm{LDH}$ content from the pellets was marked as apoptotic cells $\left(\mathrm{LDH}_{\mathrm{p}}\right)$. The extracellular $\mathrm{LDH}$ in the culture supernatant was marked as necrotic cells $\left(\mathrm{LDH}_{\mathrm{e}}\right)$, and the $\mathrm{LDH}_{\mathrm{i}}$ present in the adherent viable cells was used as intracellular LDH.

\subsubsection{Microscopic studies}

Phase contrast microscopy (carl zeiss microscope) was used for determining growth inhibition property of the alkaloid on untreated and treated HeLa cell population.

Nuclear fragmentation and mitochondrial membrane potential changes were performed using 4', $6^{\prime}$-diamidino-2-phenylindole (DAPI) $(5 \mu \mathrm{M})$ and JC-1 $(7 \mu \mathrm{M})$ dye obtained from Sigma respectively, in control and treated cells $\left(2 \times 10^{4}\right.$ cells $/ \mathrm{mm}$ in $35 \mathrm{~mm}$ culture plate) by OLYMPUS fluorescence microscope.

Comet assay (single cell gel electrophoresis) was performed on single HeLa cells to find out nuclear fragmentation which is again an important apoptosis indicator [20,28]. $0.5 \mathrm{mg} / \mathrm{mL}$ ethidium bromide solution of was added to the gel and the stained DNA in the cells was examined at $\times 200$ magnification with the help of OLYMPUS Fluorescence Microscope. The percentage of the DNA damage was measured using the software CASP.

Besides that, after fixing the cells $\left(2 \times 10^{4}\right.$ cells $/ 35 \mathrm{~mm}$ culture plate $)$ with $4 \%$ paraformaldehyde (Sigma) solution, they were cleaned by tetrachloromethane, air-dried and the gold coating was performed by IB2 ION COATER. Then, three dimensional morphology of control and treated (with $28 \mu \mathrm{M}$ harmaline) cells was studied by Cambridge 250 scanning electron microscope (SEM).

\subsubsection{Cell cycle arrest study}

HeLa cells after growing at a density of $2 \times 10^{5}$ cells $/ \mathrm{mL}$ in $35 \mathrm{~mm}$ culture plate were treated with 13,28 and $37 \mu \mathrm{M}$ of harmaline for $48 \mathrm{~h}$ and stained with propidium iodide (PI). The experimental protocol was followed an earlier report $[20,26]$. The histograms were obtained by BD Science FACS (Caliber), and the data were analyzed using the Cyflogic software.

\subsubsection{Quantitative analysis of intracellular reactive oxygen species (ROS) generation by flow cytometry}

HeLa cells $\left(2 \times 10^{5} / 35 \mathrm{~mm}\right.$ culture petridish $)$ were treated with harmaline $(28 \mu \mathrm{M})$ for 8 and $16 \mathrm{~h}$ and thereafter incubated with DCFH-DA $(20 \mu \mathrm{M})$. Intracellular ROS was determined and quantified by fluorescence-activated cell sorter (BD Science Calibur).

\subsection{Statistical Analysis}

MTT assay data are statistically analyzed with ANOVA test, and significant values are calculated against both untreated as well as solvent control $(P<0.05$ vs. solvent control). Every data is representative of three independent experiment.

\subsection{Spectroscopic and Calorimetric Experiments}

We used Jasco V-630 spectrophotometer (Jasco International Co. Ltd. Tokyo, Japan) to perform the absorbance measurements. After addition of the alkaloid to the CT DNA solution $(40 \mu \mathrm{M})$ each time, from the absorbance at the isosbestic point at $393 \mathrm{~nm}$ for the CT DNA, the total drug concentration $(\mathrm{Ct})$ present was calculated as $\mathrm{C}_{\mathrm{t}}=\mathrm{A}_{\text {iso }}$ / $\varepsilon_{\max }$. This quantity was used to calculate the expected absorbance $\left(\mathrm{A}_{\exp }\right)$ at wavelength maximum, $\mathrm{A}_{\exp }=\mathrm{C}_{\mathrm{t}} \mathrm{e}_{\max }$. The difference in $\mathrm{A}_{\text {exp }}$ and the observed absorbance $\left(\mathrm{A}_{\text {obsd }}\right)$ was then used to find out the total amount of bound harmaline as $\mathrm{C}_{\mathrm{b}}=\mathrm{A} / \Delta \varepsilon=\left(\mathrm{A}_{\exp }-\mathrm{A}_{\text {obsd }}\right) /(\mathrm{ef}-\mathrm{eb})$. Free harmaline concentration was obtained by the difference, $\mathrm{C}_{\mathrm{f}}=\mathrm{C}_{\mathrm{t}}-\mathrm{C}_{\mathrm{b}}$. The molar extinction coefficient of completely bound harmaline was determined by adding a known quantity of harmaline to a large amount of DNA polymer and on the assumption of total binding, $\varepsilon_{\mathrm{b}}=\mathrm{A}_{\max } / \mathrm{C}_{\mathrm{t}}$. This binding data was plotted into Scatchard plots $\left(r / C_{f}\right.$ versus $r$ where $r$ is the number of moles of harmaline bound per mole of DNA nucleotide) which was studied further for cooperative binding using the following equation of McGhee and von Hippel (McGhee, and von Hippel, 1974).

$$
\frac{\mathrm{r}}{\mathrm{C}_{\mathrm{f}}}=\mathrm{K}_{\mathrm{i}}(1-\mathrm{nr}) \times\left(\frac{(2 \omega+1)(1-\mathrm{nr})+(\mathrm{r}-\mathrm{R})}{2(\omega-1)(1-\mathrm{nr})}\right)^{(\mathrm{n}-1)}\left(\frac{1-(\mathrm{n}+1) \mathrm{r}+\mathrm{R}}{2(1-\mathrm{nr})}\right)^{2}
$$

Where, $\mathrm{R}=\left\{[1-(\mathrm{n}+1) \mathrm{r}]^{2}+4 \omega \mathrm{r}(1-\mathrm{nr})\right\}^{1 / 2}, \mathrm{~K}_{\mathrm{i}}$ is the intrinsic binding constant to an isolated binding site, $\mathrm{n}$ is the number of base pairs excluded by the binding of a single drug molecule and $\omega$ is the cooperative factor. The binding data were analyzed using Origin 7.0 (Origin Lab Corporation, Southampton, MA, USA) software.

DNA Melting data were recorded on a Jasco V-630 unit associated with a Peltier controlled Jasco PAC-743 model accessory (Jasco International Co. Ltd. Tokyo, Japan). The experimental protocols are same as described previously [22].

Fluorescence spectra were obtained through a Hitachi F4010 fluorescence spectrometer (Hitachi Ltd., Tokyo, Japan) in fluorescence free quartz cells having $1 \mathrm{~cm}$ path length. The excitation wavelength for the drug was $376 \mathrm{~nm}$, and the experiment was performed at $25 \pm$ $0.5^{\circ} \mathrm{C}$. The excitation and emission band passes were 2.5 and $10 \mathrm{~nm}$, respectively. Quantum yield calculations were performed following the equation of Parker and Rees (1960) as described earlier [25],

$\mathrm{f}_{\mathrm{s}}=\left(\mathrm{F}_{\mathrm{s}} \varepsilon_{\mathrm{q}} \mathrm{C}_{\mathrm{q}} \times 0.55\right) /\left(\mathrm{F}_{\mathrm{q}} \cdot \varepsilon_{\mathrm{s}} \mathrm{C}_{\mathrm{s}}\right)$ 
Where, $\mathrm{F}$ is the integrated area of the fluorescence emission curve in an arbitrary unit, e represents the molar extinction coefficient and $\mathrm{C}$ represents the molar concentration of sample (s) and quinine sulfate (q), respectively. Quinine sulfate in $0.1 \mathrm{~N}_{2} \mathrm{SO}_{4}$ was utilized as reference standard for quantum yield measurements.

CD spectra were measured on a Jasco J815 spectropolarimeter attached to a temperature controller, temperature programmer (model PFD $425 \mathrm{~L} / 15$ ) and a PC, as described previously [21,22,23,29].

GE Microcal Isothermal calorimeter (ITC) 200 (Northampton, USA) was used for ITC experiment, and Origin 7.0 software was used for the analysis.

\subsection{Analysis of Mode of Binding}

Using anionic quencher $[\mathrm{Fe}(\mathrm{CN}) 6]^{4}-$, fluorescence quenching study was performed as described previously $[28,29]$. The data were plotted as Stern-Volmer plots of Io/I versus $[\mathrm{Fe}(\mathrm{CN}) 6]^{4}{ }^{4}$.

A Cannon-Manning Type 75 semi-micro viscometer was used. Linear sonicated CT DNA was used as the sample, as described earlier [25]. Relative viscosities for DNA, both in the presence or absence of harmaline was calculated from the relation.

$$
\frac{\eta \mathrm{sp}}{\eta \mathrm{sp}}=\frac{\left[\frac{\mathrm{t}_{\text {complex }}-\mathrm{t}^{\prime} \mathrm{o}}{\mathrm{t}^{\prime} \mathrm{o}}\right]}{\left[\frac{\mathrm{t}_{\text {control }}-\mathrm{t}_{\mathrm{o}}}{\mathrm{t}_{\mathrm{o}}}\right]}
$$

Where, $h \phi_{\mathrm{sp}}$ and $\mathrm{h}_{\mathrm{sp}}$ are specific viscosities of the alkaloid-nucleic acid complex and the nucleic acid respectively, $t_{\text {complex }}, t_{\text {control }}, t \phi_{o}$ and $t_{o}$ are the average flow times for the complex, free nucleic acid, solvent for the complex and solvent for the free nucleic acid respectively.

\section{RESULTS AND DISCUSSIONS}

\subsection{Cell Viability Study and Other Biochemical Assays}

Growth inhibition capacity of Harmaline against one of the most prevalent human cervical cancer cell lines, HeLa and normal epithelial cell line, WRL-68 was studied by MTT assay. HeLa and WRL68 cells were treated with different concentrations of harmaline (10, $20,30,40$, and $50 \mu \mathrm{M})$ at $37^{\circ} \mathrm{C}$ for $48 \mathrm{~h}$ [Figure 2a]. It was found that harmaline has the $\mathrm{GI}_{25}, \mathrm{GI}_{50}$ and $\mathrm{GI}_{75}$ values of $13 \mu \mathrm{M}, 28 \mu \mathrm{M}$ and $37 \mu \mathrm{M}$, respectively, in HeLa cells; while no prominent growth inhibition was found in WRL-68 cells after harmaline treatment till

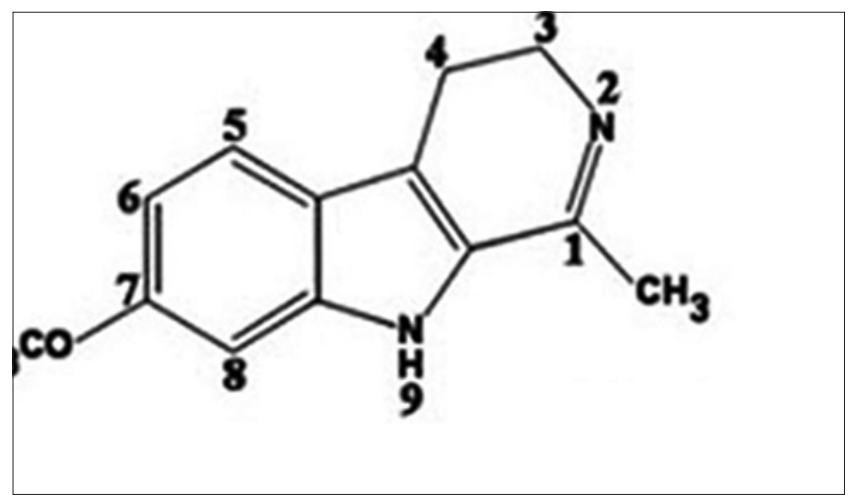

Figure 1: Chemical structure of harmaline.
$50 \mu \mathrm{M}$. These findings clearly indicated that the alkaloid has a strong growth inhibition property on epithelial cancer cells in comparison to the normal epithelial cell line. To further strengthen the finding, LDH assay was performed. This assay resulted in $4.7 \pm 1.1 \%$ necrotic, $58.5 \%$ $\pm 1.2 \%$ apoptotic and $36.8 \pm 0.90 \%$ viability in harmaline treated cell line, whereas, in control cell line the values were $4.8 \pm 1.2 \%, 11.2 \pm$ $0.9 \%$, and $84.0 \pm 2.1 \%$, respectively [Figure $2 b$ ].

Nucleic acid-specific fluorochromes emit different fluorescent color when bound to target nucleic acids and this event can be observed under fluorescence microscopy [20]. Cellular morphological changes such as rounding of cell contour and fragmentation of nucleus were determined by phase contrast microscopic images [Figure 2c]. With increasing drug treatment, HeLa cells revealed increasing oligonucleosomal fragmentation and nuclear condensation after treatment with DAPI [Figure 2d]. Comet assay was performed thereafter, that showed DNA strand breaks in the comet tail constituting of $24 \pm 1.0 \%$ amount of DNA after $\mathrm{GI}_{50}$ dose $(28 \mu \mathrm{M})$ treatment and the values were calculated by software CASP [Figure 2e and $\mathrm{f}$. We further performed mitochondrial membrane potential assay using JC1 , a voltage sensitive fluorescent cationic dye, which accumulates in mitochondria after sensitizing different voltage and indicates decrease in membrane potential by a fluorescence emission change from red to green [Figure 2g]. Morphologic description of apoptosis using SEM still remains one of the best ways to define apoptosis as apoptotic cells contain many morphological alterations than control cells [20]. To validate our previous results, the three-dimensional morphological changes in control and harmaline treated cells were observed by SEM [Figure 2h]. While, untreated HeLa cells have shown the typical morphological features of cervical cancer cells which include cell surface projections, several morphological alterations (namely membrane blebbing, cell shrinkage etc) were observed in a large number of treated cells.

PI staining for cell cycle analysis indicates aggregation of cell population at G2/M stage, the detailed result is depicted in Table 1 [Figure $3 \mathrm{a}$ and $\mathrm{b}$ ]. ROS generation is a key role of many anticancer compounds [32]. Furthermore, cancer is a probable cause of various chemical induced ROS dependent stresses in the body [33]. Maximum of the chemotherapeutic agents inhibit cancer cells growth by preventing intracellular ROS elevation [33]. In this study, harmaline has been shown to cause ROS mediated apoptosis in the cancer cell line with a subsequent cell cycle arrest at G2/M phase, thereby acting as a chemotherapeutic agent. The effects of harmaline on HeLa cells were found to be time-correlated as observed by the flow cytometric quantification of ROS generation study after adding DCFH-DA in harmaline treated $(28 \mu \mathrm{M})$ cells for 8 and $16 \mathrm{~h}$ [Figure 3c]. It was measured using excitation/emission wavelengths of 500/520 nm as reported earlier [20].

As the alkaloid shows nuclear fragmentation targeting DNA, several spectroscopic and calorimetric analyses were performed to emphasize the mode and mechanism of binding with CT DNA.

\subsection{Spectroscopic and Calorimetric Studies}

The characteristic ultraviolet (UV)- visible spectrum of harmaline (red color) at pH 6.8 exhibits maxima at 205, 258, and $371 \mathrm{~nm}$, respectively, in the range of $200-550 \mathrm{~nm}$. With increasing concentration of CT DNA, characteristic hypochromic (27.4\%) effect and bathochromic shift $(7 \mathrm{~nm})$ was observed [Figure 4a]. The hypochromic effect essentially indicates strong intermolecular interaction involving effective overlap of the $\pi$ electron cloud of harmaline with the nucleotide bases. The 
spectra show prominent isosbestic point at $393 \mathrm{~nm}$, indicating equilibrium. The findings from UV spectroscopic absorption titration of increasing concentration of harmaline to a fixed concentration of CT DNA was expressed in the form of Scatchard plot $\left(r / C_{f}\right.$ versus $\left.r\right)$ and found to be a non-linear curve [Figure 4a]. In the case of CT DNA with harmaline, where a positive slope was observed at low values of bound alkaloid, the analysis for cooperative binding was performed using the McGhee-von Hippel Eq. (4). Generally, cooperative binding

Table 1: Percentage of HeLa cell population at the various cell cycle stages ${ }^{\mathrm{a}}$.

\begin{tabular}{lcccc} 
Drug concentration $(\boldsymbol{\mu M})$ & Sub G0/G1 cell population $(\%)$ & $\begin{array}{c}\text { G0/G1 cell } \\
\text { population (\%) }\end{array}$ & $\begin{array}{c}\text { S cell } \\
\text { population (\%) }\end{array}$ & $\begin{array}{c}\text { G2/M cell } \\
\text { population (\%) }\end{array}$ \\
Control & $0.82 \pm 0.3$ & $85.08 \pm 1.03$ & $3.31 \pm 0.5$ & $10.79 \pm 0.5$ \\
13 & $1.57 \pm 0.3$ & $66.61 \pm 1.0$ & $12.39 \pm 0.9$ & $19.43 \pm 0.9$ \\
28 & $8.67 \pm 0.5$ & $40.98 \pm 0.5$ & $16.44 \pm 1.0$ & $33.91 \pm 0.7$ \\
37 & $8.72 \pm 0.9$ & $36.67 \pm 0.3$ & $17.45 \pm 1.0$ & $37.16 \pm 1.0$ \\
\hline
\end{tabular}

aAverage of three experiments are presented here and the means are significant compared with their control $(P<0.05)$.

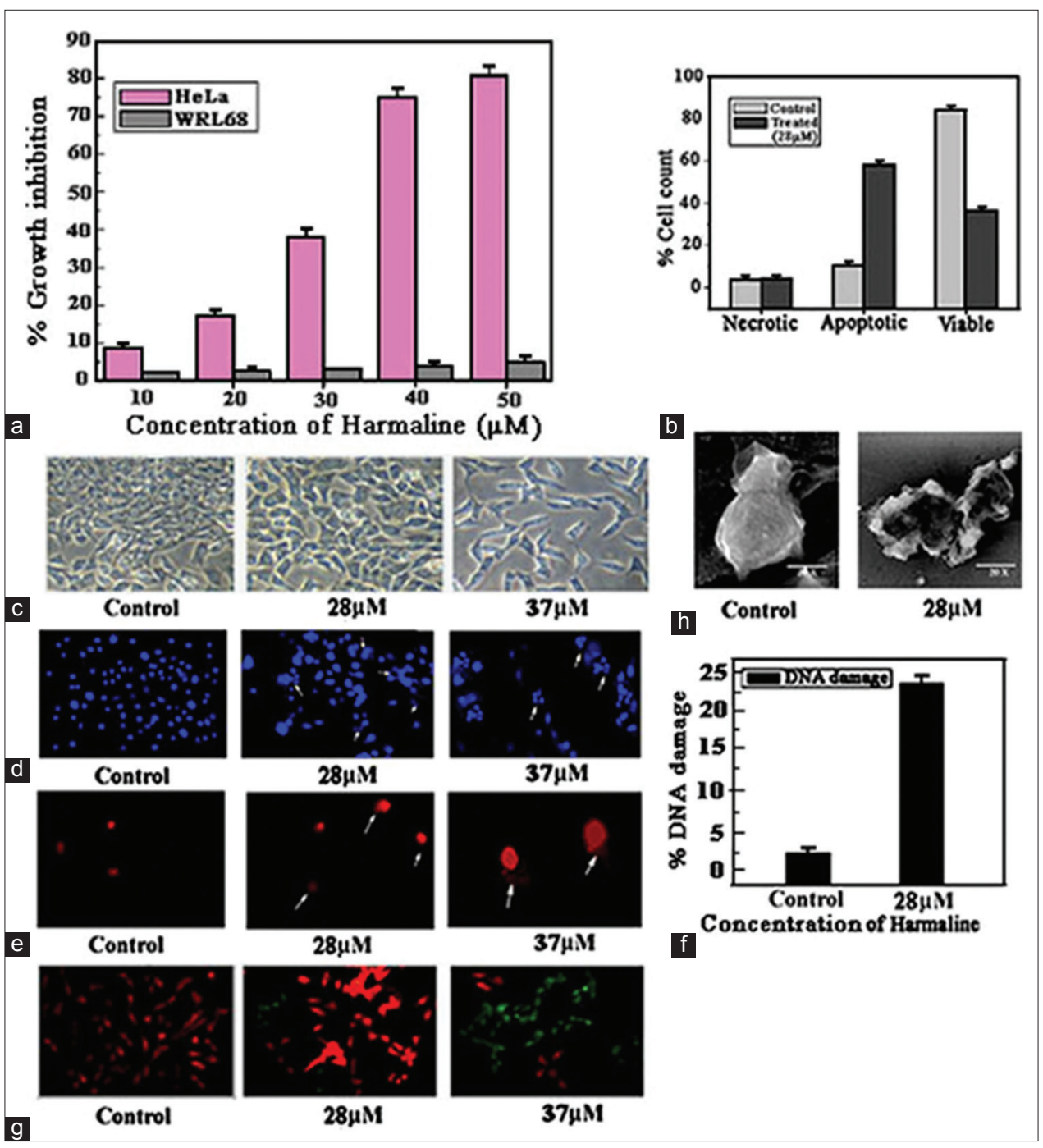

Figure 2: (a) MTT assay on HeLa and WRL-68 cell lines after harmaline treatment of various concentrations (13, 20, 30, and 40 $\mu \mathrm{M})$ for 48 h. Data are statistically analyzed with ANOVA test and significant values are calculated against both untreated as well as solvent control ( $P<0.05$ vs. solvent control), (b). LDH assay performed after harmaline treatment to find out percentage of apoptotic and necrotic cell death. Data represent three independent experiments, (c). Phase contrast microscopic images $(\times 200)$ of control and treated HeLa cells, (d). Nuclear fragmentation of HeLa cells induced by $28 \mu \mathrm{M}$ and $37 \mu \mathrm{M}$ harmaline in comparison to control cells after staining the nuclei with DAPI and observed under a fluorescence microscope $(\times 200)$, (e). Comet assay showing prominent comet tails harmaline treatment indicative of DNA damage, (f). Comet assay bar graph representing \% DNA damage in HeLa cells after drug treatment $\left(\mathrm{GI}_{50}\right)$ by software CASP. The graph represents the mean \pm standard deviation of three independent experiments, $(\mathrm{g})$. HeLa cells were treated with and then subjected to JC-1 staining to evaluate the changes in mitochondrial membrane potential viewed under fluorescence microscope $(\times 200)$, (h). Changes in cell shape and contour after $28 \mu \mathrm{M}$ harmaline treatment as observed under S530 Hitachi scanning electron microscope. 
is mediated by allosteric effects [21,24,25,29-31]. Scatchard plot from the interaction of harmaline with CT DNA indicates [inset of Figure $4 \mathrm{a}$ ] intrinsic binding affinity, $\mathrm{K}_{\mathrm{i}} \omega$ (product of cooperative binding affinity and the cooperative factor) in the order of $5.60 \times$
$10^{5} / \mathrm{M}$ with a stoichiometry of 4 nucleotide phosphates. The binding constant value was quiet close to the previous result by Nafisi et al., 2010 [9]. Stabilization of the alkaloid to CT DNA was also studied by optical melting experiment, which revealed that the native melting

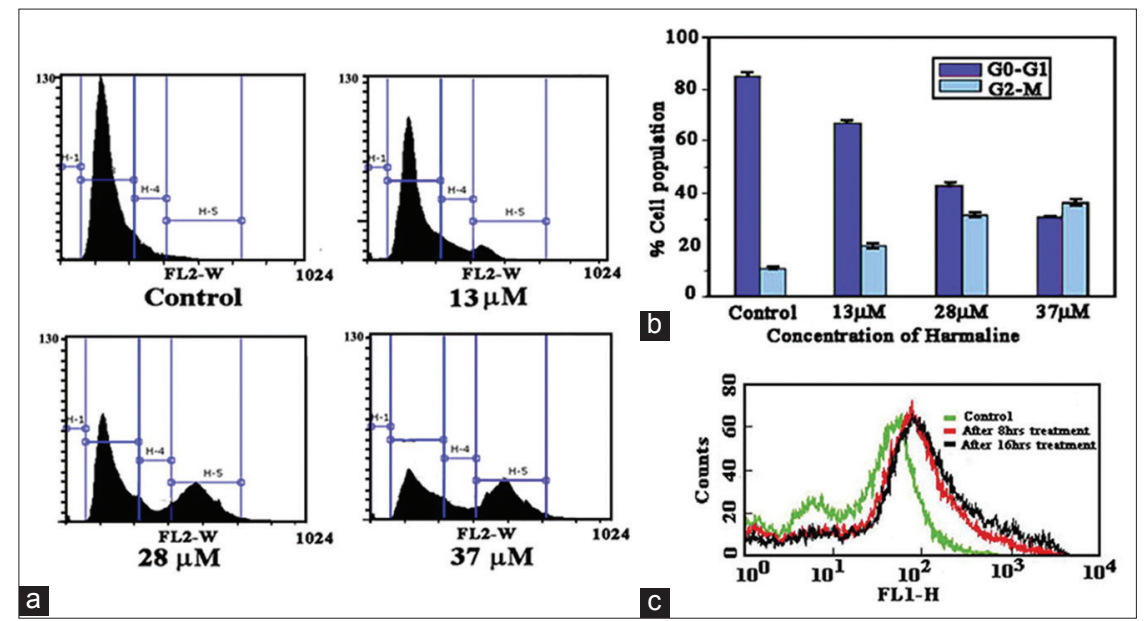

Figure 3: (a). Histrogram of HeLa (Control and treated with 13, 28 and $37 \mu \mathrm{M}$ of harmaline), obtained from FACS analysis after staining with propidium iodide. (b). Bar graph represents the values of cell count in G0/G1 and G2/M phase for control and treated cells with increasing concentrations (13, 28 and $37 \mu \mathrm{M})$ of harmaline. Three independent experiments were performed and the means are significant in comparison with their control $(P<0.05)$. Complete data is presented in Table 1, (c). Harmaline induced ROS generation in HeLa cells. HeLa cells were cultured in absence (control, green) and presence of harmaline for the specified time period. DCFDH-DA fluorescence intensity was detected by using flow cytometry.

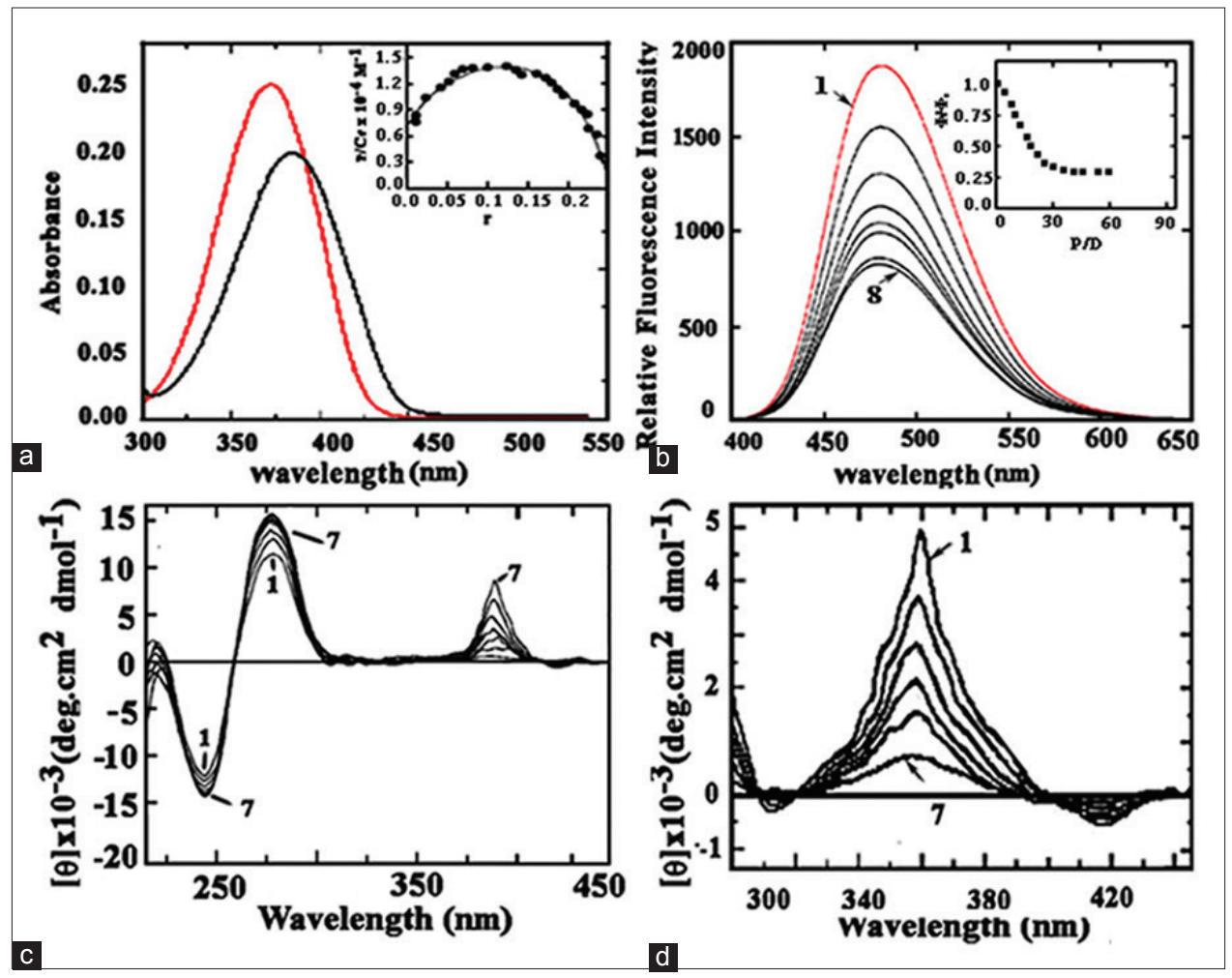

Figure 4: (a). Absorption spectra of harmaline $(10 \mu \mathrm{M})$ in $15 \mathrm{mM} \mathrm{CP}$ buffer, $\mathrm{pH} 6.8$ at $25 \pm 0.5^{\circ} \mathrm{C}$ (red spectra) and with treatment of $53.45 \mu \mathrm{M} \mathrm{CT}$ DNA (black spectra); (insight) Scatchard plots derived from absorbance spectral data for the binding of harmaline to $20 \mu \mathrm{M}$ of CT DNA. The data was fit to the cooperative binding model derived from McGhee-von Hippel equation, (b). Steady state fluorescence emission spectrum of harmaline ( $3 \mu \mathrm{M}$, red colour spectra) to 7.20, $15.60,28.90,34.40,48.40,54.30,63.10$ and $72.6 \mu \mathrm{M}$ (curves 2-8) of concentrations CT DNA $\mu \mathrm{M}$ of CT DNA and plots (Inset) of the relative quantum yield $\phi / \phi_{\square}$ versus P/D for the interaction of harmaline ( $-\mathbf{m})$ with CT DNA, (c). CD spectra resulting from the interaction of harmaline with CT DNA (65 $\mu \mathrm{M})$ in $15 \mathrm{mM}$ CP buffer of pH 6.8 at $25 \pm 0.5^{\circ} \mathrm{C}$. Curves $1-7$ denote CT DNA $(65 \mu \mathrm{M})$ treated with $0,5.0,12.0,15.0,36.5,48.7$ and $55.0 \mu \mathrm{M}$ of harmaline (d). Extrinsic CD spectra 
temperature of CT DNA $\left(67^{\circ} \mathrm{C}\right)$ at $15 \mathrm{mM}$ is stabilized to $10^{\circ} \mathrm{C}$ in the presence of alkaloid [Figure not shown].

Fluorescence emission spectra of harmaline-DNA interaction were recorded in 400-650 $\mathrm{nm}$ [Figure 4b]. The alkaloid was found to be a strong fluorophore having emission spectral peak at $480 \mathrm{~nm}$ when exited at $376 \mathrm{~nm}$ and showed $56 \%$ quenching of steady state fluorescence intensity during the interaction. The quantum yield $\left(\phi / \phi_{\mathrm{o}}\right)$ of the alkaloid-DNA complexes [Table 2] depicts a value of 0.29 at saturation P/D 24.2 [inset of Figure 4b].

Conformational changes of CT DNA- harmaline was studied by circular dichroism (CD) [21,23,34-36] [Figure 4c]. The intrinsic CD spectra of the CT DNA-alkaloid interaction at $\mathrm{pH} 6.8$ shows a regular and prominent perturbation in the $278 \mathrm{~nm}$ positive peak while the

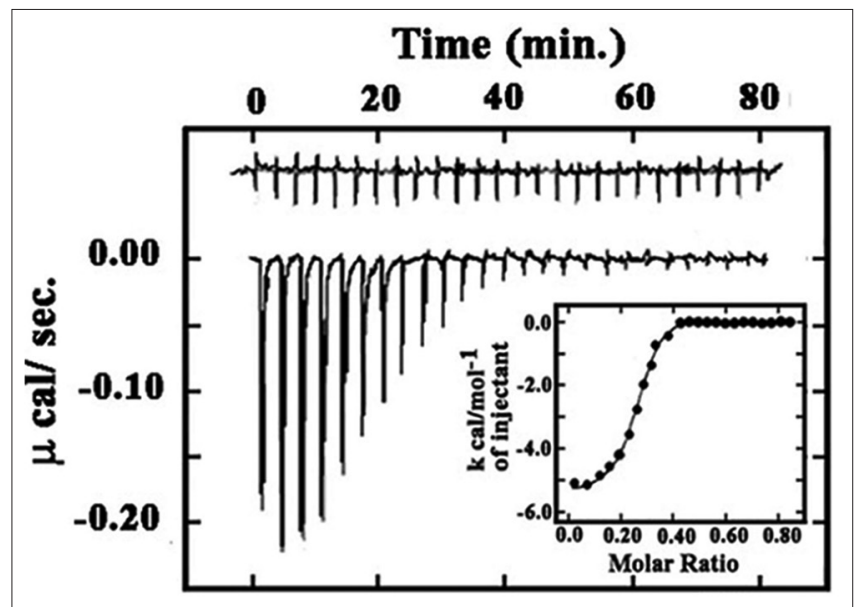

Figure 5: Isothermal calorimeter profile for binding of $1200 \mu \mathrm{M}$ of CT DNA to harmaline $(22 \mu \mathrm{M})$ at $25 \pm 0.5^{\circ} \mathrm{C}, \mathrm{pH}$ 6.8. Each heat burst curve (in the bottom part of upper panel) is due to the $1.5 \mu \mathrm{L}$ sequential injection of the DNA into the alkaloid (curves at the bottom). The data points (--匹) reflect the experimental injection heats while the solid line represents the calculated best fit of the data. The values of the various thermodynamic parameters obtained are presented in Table 2 .
$242 \mathrm{~nm}$ negative peak show only slight changes in molar ellipticity. A prominent extrinsic CD peak in the region of $376 \mathrm{~nm}$ [Figure 4d] was also obtained.

A thermodynamic study through ITC was performed which is a direct methodology of interpreting various thermodynamic parameters in various bio molecular interaction studies [37-39]. A reversed protocol was used throughout the experiment as the alkaloid has high heat of dilution [Figure 5]. Previously, Yang et al. and Du et al. (2004) had reported the thermodynamic parameters for the interaction of beta carboline derivatives with DNAs [40,41]. The thermodynamic data are depicted in Table 2 and the binding constant $\left(\mathrm{K}_{\mathrm{b}}\right)$ and stoitiometry $(\mathrm{N})$ of $5.60 \pm 0.02 \times 10^{5} / \mathrm{M}$ and 4.0, respectively, have been found which are in good agreement with the spectrophotometric data. Furthermore, the large negative enthalpy change of $-5.10 \pm 0.02 \mathrm{kcal} / \mathrm{mol}$ has been reported which is typical case for intercalative binding of the drug -DNA interaction [42].

\subsection{Mode of Binding}

The binding mode of harmaline to the sonicated CT DNA has been studied by viscosity experiments [Figure 6a]. As the D/P (alkaloid/ nucleotide phosphate) increase, the relative specific viscosity of CT DNA-harmaline complex increased sharply, suggesting the intercalation of the alkaloid into the DNA helix. The changes were due to the increase in the axial length of the DNA and it becomes more rigid after binding with the alkaloid. Hence, the viscosity increases as both the factors enhanced the frictional coefficient. The above changes were compared with CT DNA-ethidium bromide complexation as ethidium is used as a classical intercalator.

Ferrocyanide $\left(\left[\mathrm{Fe}(\mathrm{CN})_{6}\right]^{4-}\right)$ quenching is another reliable method for studying the mode of binding of ligands to nucleic acids. The study shows a $\mathrm{K}_{\mathrm{sv}}$ value of $177 \pm 1.2 \mathrm{M}^{-1}$ for free harmaline with ferrocyanide. While that of bound molecule to CT DNA was $56.7 \pm 0.7 \mathrm{M}^{-1}$ indicating that the bound alkaloid was considerably sheltered and sequestered away from the solvent suggesting good stacking inside the DNA helix [Figure 6b].

\section{CONCLUSION}

For the development of a drug it is an absolute necessity to understand the molecular interaction of the drug and its cellular target molecules.

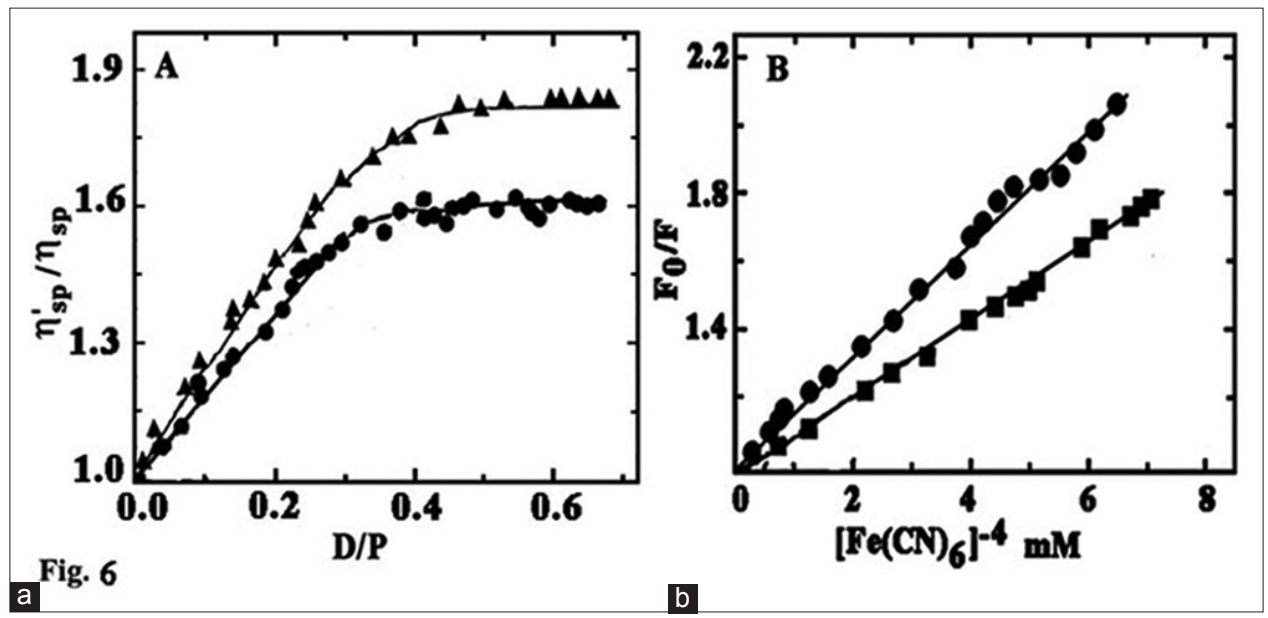

Figure 6: (a). Plot of changes of relative specific viscosity of sonicated $(\bullet-\bullet)$ CT DNA with increasing concentration of harmaline. The relative specific viscosity of the polymer was compared with the change in specific viscosity of CT DNA with ethidium ( $\mathbf{\Delta}-\mathbf{\Delta})$. The specific viscosity was calculated from equation (6) described in text. The concentration of DNA was $450 \mathrm{mM}$, respectively, (b). Stern-Volmer plots for quenching by increasing concentration of $\left[\mathrm{Fe}(\mathrm{CN})_{6}\right]^{-4}$ with harmaline in the absence of polymer $(\bullet-\bullet)$ and in the presence of $(\boldsymbol{\bullet - \bullet})$ CT DNA. The corresponding $\mathrm{K}_{\mathrm{sv}}^{\prime}$ values are presented in Table 2. 


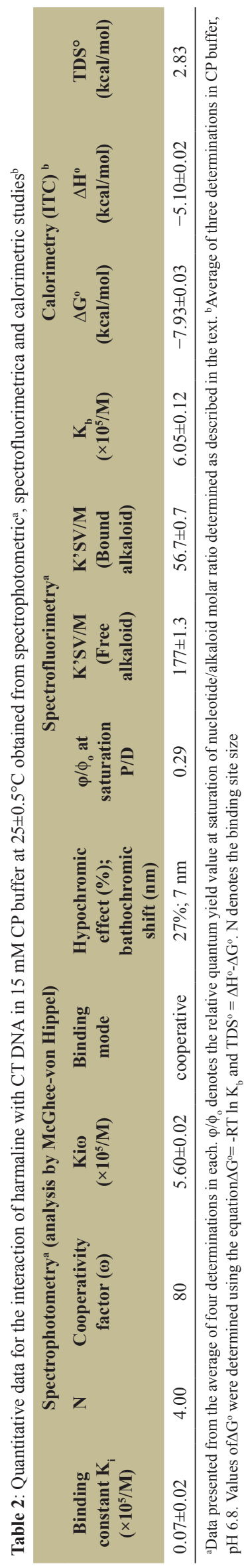

Results of our study revealed that harmaline have potent cytotoxic property by inducing ROS dependent apoptosis in the human cervical cancer cell line, HeLa and furthermore, shows conformational changes in DNA. Hence, this research work is providing sufficient informations to conclude harmaline as a potent chemotherapeutic drug against human cervical cancer and will be developed in future as a better and effective beta carboline derivative for biomedical uses.

\section{ACKNOWLEDGMENTS}

PB has been supported by grant from University of Kalyani. SS and TG are supported by DST, WB and UGC respectively. Authors are thankful to DST-RFBR 2017-19 (DST/INT/RUS/RFBR/P-254) and PRG-2017-18, University of Kalyani and to the Department of Environmental Science, University of Kalyani for providing spectrofluorimeter and fluorescence microscope facility.

\section{REFERENCES}

1. Jemal A, Bray F, Center MM, Ferlay J, Ward E, Forman D, et al. Global cancer statistics. CA Cancer J Clin 2011;61:69-90.

2. Ali R1, Mirza Z, Ashraf GM, Kamal MA, Ansari SA, Damanhouri GA. New anticancer agents: Recent developments in tumor therapy. Anticance Res 2012;32:2999-3005.

3. Bhadra K, Kumar GS. Therapeutic potential of nucleic acid-binding isoquinoline alkaloids: Binding aspects and implications for drug design. Med Res Rev 2011;31:821-62.

4. Moudi M, Go R, Yien CY, Nazre M. Vinca alkaloids. Int J Prev Med 2013;4:1231-5.

5. Roberts MF, Wink M. Ecology and Medicinal Applications, Alkaloids. New York, London: Plenum Press; Biochemistry; 1998. p. 1-7.

6. Kumar GS. Isoquinoline alkaloids and their analogs: Nucleic acid and protein binding aspects, and therapeutic potential for drug design. In: Brahmachari G, editor. Bioactive Natural Products: Chemistry and Biology. Germany: Wiley-VCH Verlag GmbH \& Co. KGaA; 2015. p. 241-77.

7. Bournine L, Bensalem S, Fatmi S, Bedjou F, Mathieu V, IguerOuada M, et al. Evaluation of the cytotoxic and cytostatic activities of alkaloid extracts from different parts of Peganum harmala L. (Zygophyllaceae). Eur J Integ Med 2016;9:91-6.

8. Zeng Y, Zhang Y, Weng Q, Hu M, Zhong G. Cytotoxic and Insecticidal Activities of derivatives of harmine, a natural insecticidal component isolated from Peganum harmala. Molecules 2010;15:7775-91.

9. Nafisi S, Bonsaii M, Maali P, Khalilzadeh MA, Manouchehri F. $\beta$-carboline alkaloids bind DNA. J Photochem Photobio B Biol 2010;100:84-91.

10. Berrougui $\mathrm{H}$, Isabelle $\mathrm{M}$, Cloutier $\mathrm{M}$, Hmamouchi M, Khalil A. Protective effects of Peganum harmala L. extract, harmine and harmaline against human low-density lipoprotein oxidation. J Pharm Pharmacol 2006;58:967-74.

11. Mahmoudian M, Jalilpour H, Salehian P. Toxicity of Peganum harmala: Review and a case report. Iran J Pharmacol Therap 2002;1:1-4.

12. Di Giorgio C, Delmas F, Ollivier E, Elias R, Balansard G, TimonDavid P. In vitro activity of the beta-carboline alkaloids harmane, harmine, and harmaline toward parasites of the species Leishmania infantum. Exp Parasitol 2004;106:67-74.

13. Rharrabe K, Bakrim A, Ghailani N, Sayah F. Bioinsecticidal effect of harmaline on Plodia interpunctella development (lepidoptera pyralidae). Pestic Biochem Physiol 2007;89:137.

14. Zheng XY, Zhang ZJ, Chou GX, Wu T, Cheng XM, Wang CH, et al. Acetylcholinesterase inhibitive activity-guided isolation of two new alkaloids from seeds of Peganum nigellastrum Bunge by an in vitro 
TLC-bioautographic assay. Arch Pharmacol Res 2009;32:1245-51.

15. Herraiz T. Identification and occurrence of beta-carboline alkaloids in raisins and inhibition of monoamine oxidase (MAO). J Agric Food Chem 2007;55:8534-40.

16. Sobhani AM, Ebrahimi SA, Mahmoudian M. An in vitro evaluation of human DNA topoisomerase I inhibition by Peganum harmala L. Seeds extract and its beta-carboline alkaloids. J Pharm Pharm Sci 2002;5:19-23.

17. Berrougui H, Lopez-Lazaro M, Martin-Cordero C, Mamouchi M, Ettaib A, Herrera MD. Cytotoxic activity of methanolic extract and two alkaloids extracted from seeds of Peganum harmala L. J Nat Remedy 2005;5/1:41-5.

18. Ayoob I, Hazari YM, Lone SH, Rehman S, Khuroo MA, Fazili KM, et al. Phytochemical and cytotoxic evaluation of Peganum harmala: Structure activity relationship studies of harmine. Med Chem Drug Discov DOI: 10.1002/slct.201700232.

19. Cao R, Peng W, Wang Z, Xu A. b-Carboline alkaloids: Biochemical and pharmacological functions. Curr Med Chem 2007;14:479-500.

20. Sarkar S, Bhattacharjee P, Bhadra K. DNA binding and apoptotic induction ability of harmalol in HepG2: Biophysical and biochemical approaches. Chem Biol Interact 2016;258:142-52.

21. Sarkar S, Pandya P, Bhadra K. Sequence specific binding of betacarboline alkaloid harmalol with deoxyribonucleotides: Binding heterogeneity, conformational, thermodynamic and cytotoxic aspects. PLoS One 2014;9:1-14.

22. Bhattacharjee P, Sarkar S, Pandya P, Bhadra K. Targeting different RNA motifs by beta carboline alkaloid, harmalol: A comparative photophysical, calorimetric and molecular docking approach. J Biomol Struct Dyn 2016;34:2722-40.

23. Sarkar S, Bhadra K. Binding of alkaloid harmalol to DNA: Photophysical and calorimetric approach. J Photochem Photobio B Biol 2014;130:272-80.

24. Bhadra K, Maiti M, Kumar GS. Berberine-DNA complexation: New insights into the cooperative binding and energetic aspects. Biochim Biophys Acta (BBA) Gen Subj 2008;1780:1054-61.

25. Sinha R, Islam MM, Bhadra K, Kumar GS, Banerjee A, Maiti M, et al. The binding of DNA intercalating and non-intercalating compounds to A-form and protonated form of poly $(\mathrm{rC})$.poly $(\mathrm{rG})$ : Spectroscopic and viscometric study. Bioorg Med Chem 2006;14:800-14.

26. Chatterjee S, Mallick S, Buzzetti F, Fiorillo G, Syeda TM, Lombardi P, et al. New 13-pyridinealkyl berberine analoguesintercalate to DNA and induce apoptosis in $\mathrm{HepG}_{2}$ and MCF-7 cells through ROS mediated p53 dependent pathway: Biophysical, biochemical and molecular modeling studies. RSC Adv 2015;5:90632-44.

27. Biswas R, Mandal SK, Dutta S, Bhattacharyya SS, Boujedaini N, Khuda-Bukhsh AR, et al. Thujone-rich fraction of Thuja occidentalis demonstrates major anti-cancer potentials: Evidences from in vitro studies on A375 cells. Evid Based Complement Alternat Med 2011;2011:568148.

28. Liao W, McNutt MA, Zhu WG. The comet assay: A sensitive method for detecting DNA damage in individual cells. Methods
2009;48:46-53.

29. Bhadra K, Maiti M, Kumar GS. Molecular recognition of DNA by small molecules: AT base pair specific intercalative binding of cytotoxic plant alkaloid palmatine. Biochim Biophys Acta 2007;1770:1071-80.

30. Das A, Bhadra K, Suresh Kumar G. Targeting RNA by small molecules: Comparative structural and thermodynamic aspects of aristololactam- $\beta$-D-glucoside and daunomycin binding to tRNA(phe). PLoS One 2011;6:e23186.

31. Islam MM, Chowdhury SR, Kumar GS. Spectroscopic and calorimetric studies on the binding of alkaloids berberine, palmatine and coralyne to double stranded RNA polynucleotides. J Phys Chem B 2009;113:1210-24.

32. Elmore S. Apoptosis: A review of programmed cell death. Toxicol Pathol 2007;35:495-516.

33. Liou GY, Storz P. Reactive oxygen species in cancer. Free Radic Res 2010;44. DOI: 10.3109/10715761003667554.

34. Bhadra K, Maiti M, Kumar GS. Interaction of isoquinoline alkaloid palmatine with deoxyribonucleic acids: Binding heterogeneity, and conformational and thermodynamic aspects. Chem Biodivers 2008;5:575-90.

35. Islam MM, Kumar GS. RNA targeting by small molecule alkaloids: Studies on the binding of palmatine and berberine to polyribonucleotides and comparison to ethidium. J Mol Struct 2008;875:382-91

36. Neidle S, Waring MJ. Molecular Aspects of Anticancer Action. Basingstoke, U.K: Macmillan Press Ltd.; 1981.

37. Buurma NJ, Haq I. Advances in the analysis of isothermal titration calorimetry data for ligand-DNA interactions. Methods 2007;42:162-72.

38. O'Brien R, Haq I, Ladbury JE. In: Doyle M, editors. Applications of Biocalorimetry: Binding, Stability and Enzyme Kinetics. Biocalorimetry. Vol. 2. West Sussex, England: Wiley John and Sons Ltd.; 2004. p. 3-253.

39. Saboury AA, Atri MS, Sanati MH, Moosavi-Movahedi AA, Hakimelahi GH, Sadeghi M, et al. A thermodynamic study on the interaction between magnesium ion and human growth hormone. Biopolymers 2006;81:120-6.

40. Du W, Wang B, Li Z. Interaction of harmine with oligonucleotide d(GTGCAC)2. Thermochim Acta 2004;416:59-63.

41. Yang M, Wang K, Zang CB, Wang BH, Zang YM. Binding of carboline derivatives to calf thymus DNA-determination of binding mode and binding strength. J Chinese Pharm Sci 1994;3:51-8.

42. Chaires JB. A thermodynamic signature for drug-DNA binding mode. Arch Biochem Biophys 2006;453:26-31.

\footnotetext{
How to cite this article:

Bhattacharjee P, Sarkar S, Ghosh T, Bhadra K. Therapeutic potential of

harmaline, a novel alkaloid, against cervical cancer cells in vitro: Apoptotic

induction and DNA interaction study. J App Biol Biotech. 2018;6(04):1-8.

DOI: $10.7324 / \mathrm{JABB} .2018 .60401$
} 